Francesco VALLERANi

\title{
Inland Waterways as Modern Landscapes in Northeast Italy: Recovering a Cultural Heritage for Sustainable Governance
}

\author{
1 Introduction
}

The succession of wetlands along the coast of the northern Adriatic and the complex fluvial and artificial canal network flowing into it are landscape elements with remarkable geomorphological features, significant settings that contribute to and enhance the complex physiognomy of northeast Italy. The low plains surrounding the shorelines of both the Adriatic Sea and the Venice lagoon are a rare and complex hydrographic setting, where natural downflows and human intervention have, over the centuries, produced a territory able to withstand the increasing weight of human activity, including that of the most recent explosion of sprawling cities. For a better understanding of these watery landscapes and the vital need for engineering control in this area of the plains we must consider the negligible gradients, the hanging form of watercourses, the importance of river banks, the precise layout of drainage ditches and the strategic role of water pumps. The ruinous floods that have hit some areas of this territory show that even countries equipped with highly sophisticated land management instruments can experience increasingly critical situations affecting the hydrographic systems both in the case of excessive and exceptionally low water flows. Beginning with this basic observation, it is worth considering a new humanistic approach to water where more specifically engineering-oriented skills could overlap with anthropological and geohistorical disciplines.

The aim of this essay is to highlight the consolidated and profitable network of nautical relations that has existed since medieval times within the specific interface between the Veneto low plain and the Venice lagoon. Navigation is actually one of the most meaningful operative activities able to express the millennial relationships between societies and waterscapes. In fact, the case considered here represents a privileged scenario providing indisputable evidence of the extraordinary variety of the waterways and of the complexity and dynamic development that have marked the co-existence of communities and water landscapes over time. Besides, this long-term evolution up to the era of industrial modernisation has produced practical interactions with 
the wide array of relevant transformations affecting the construction of new modern landscapes. The case of northeast Italy also illustrates the role of modern States (despite the recent independence of the Italian State) in the last decades of the nineteenth century, when a widespread nationalistic discourse on skilful exploitation of natural/national resources fostered large schemes exploiting advancements in water engineering for the management of river catchments as well as for the reclamation of wetlands. As a consequence, new landscapes not only spread in the lowlands, declining towards the lagoon and the shoreline, where wetlands reclamation had already been accomplished, but also in numerous Dolomite valleys with the construction of dams and new hydroelectric power plants.

Inland navigation played a key role in this context, in particular during the early years of the twentieth century when it was considered one of the preeminent factors in Italian economic growth. Most of the national waterways were located in the northeast regions, gravitating around the thriving inland harbours of Padua and Treviso, both well-connected to the commercial and industrial area of Venice. Most of the navigable rivers and canals in the Veneto and Friuli were heavily damaged in the Second World War and suffered from lack of maintenance during the ensuing economic recession. Therefore the decline of water transport led to a functional decadence of several fluvial and canal landscapes that, year after year, gave rise to a cultural detachment from this former shared 'fluvial sense of place'. It was not until more recent times that a more mature appreciation of the cultural heritage related to riverscapes developed. For this reason waterways today must be considered not only in terms of engineering but also in the light of wider cultural and recreational goals, and the undeniable relevance of rivers and canals must be borne in mind in all environmental planning measures.

It follows that the recovery of historical, iconographic and oral memory will provide a clear awareness of the heritage value of the riverside landscapes both along the main navigation routes and on secondary waterways. This approach enables us to appreciate the role of several local initiatives promoting an increasingly shared awareness of waterscapes as cultural heritage, with a significant impact not only on a cultural level but also in terms of recreation and tourism. In fact, this growing interest in the amphibious environments of inland Veneto represents a driving force for the 'rebirth' of numerous marginal landscapes located along the waterways in the lower plains of the Veneto region.

In fact, waterways no longer used for freight traffic have the most interesting and significant potential in terms of river tourism, a leisure sector now expanding throughout the western world (including latecomer Italy) and not only due 
to its attraction in terms of mobility, but also thanks to a number of significant ideological and cultural conditions in line with the aims of sustainability.

\section{Landscape Evolution and the Venetian State}

Even a brief geographical analysis shows that most of the current landscapes made up of former lowlands along the coastline are densely intersected by branches of rivers that wind lazily out to sea, often branching off into various directions well before their final destination. Here they outline lagoons, change meanders, and modify the layout of their beds, and even the contents carried by the water, interacting with the sea and motion of the waves to create that extraordinary variety of sublittoral morphology which, where not modified or fixed by human intervention, continues today to represent an undisputed environmental heritage, a refuge of biodiversity, and a vital opportunity to keep ecological awareness alive. A hydraulic apprenticeship has developed in such wet environments, leading to ever-larger and more complex interventions that have modified the natural layout of watercourses in order to improve control and divert flood water needed for fertile soil, building canals for irrigation, ditches and drain manifolds, and barriers and river banks to protect fields and houses from overflowing water.

The geomorphological nature of the sublittoral plains of the upper Adriatic features dominant and dense deposits of fine sediment, lime and sand, which reduce the permeability of the soil, thus favouring prolonged stagnation of water in the event of overflow flooding from the numerous pre-alpine rivers, such as the Brenta and the Piave. The land areas usually defined as flood plains are created by the force of water dynamics responsible for the erosive action, shifting sediments and the progressive consolidation of this land. This long process commenced during the Quaternary Period, and is linked to the gradual erosion of the alpine and pre-alpine mountains by atmospheric agents, which provided the material to fill the large Pliocene gulf formed by the Adriatic insinuating itself within the limits of the current river Po plains. ${ }^{1}$

The plains came into being during the alternating glacial eras, starting with the upper plains at the foot of the pre-alpine range. As they moved away from the raised land, the gradients of the riverbeds decreased, thus limiting their carrying capacity to fine sediments, which then became compact soil, reducing the permeability of the land. This process was particularly marked at the end of the last great glaciation (Würm glaciation), following the abundant

1 Bondesan et al. 2004. 
floods of melting water, which, by spreading freely across the lower plains, distributed enormous quantities of sediment, thus increasing the thickness of the alluvial strata. It was in this evolutionary phase that the presence of even smaller detritus deposited by the mouths of numerous rivers along the landsea interface gave rise to coastal strips and lagoons (fig. 8.1), due to the redistribution and accumulation of material by the sea and tidal currents. ${ }^{2}$ The subsequent morphological evolution of the lower plains was entirely due to the unrestricted expansion of river water, with consequent variations of the watercourses, forming elongated edges of sediments and backwaters. ${ }^{3}$

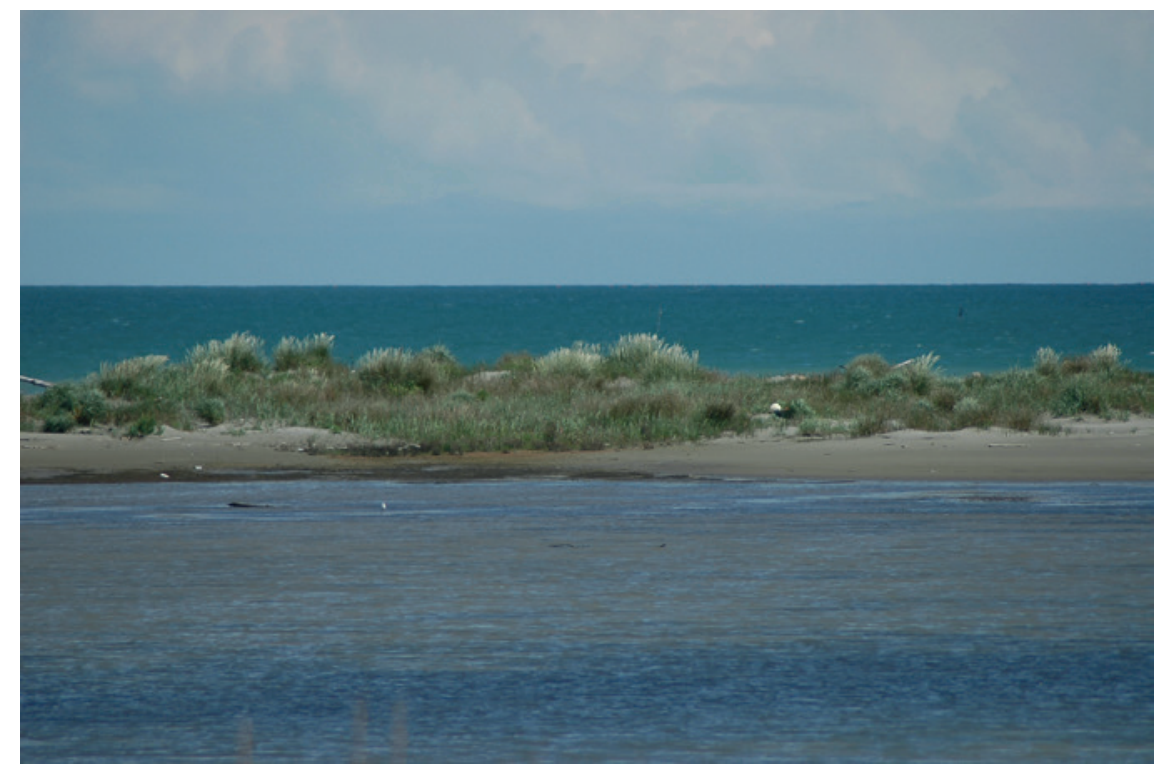

FIGURE 8.1 Land-sea interface with coastal strip in Po river delta COURTESY OF EDDI BOSCHETTI

The configuration of this section of the Veneto lower plains in its current layout is therefore the result of long-term alternating events, starting from the first significant presence of the Benedictine monks of the Paduan monastery of Santa Giustina, documented as far back as the thirteenth century, between the lower courses of the Bacchiglione and Adige rivers. ${ }^{4}$ These first interventions marked the beginning of the slow process of water control in an area that was undoubtedly among the first to be regularly protected against seasonal

2 Rotondi et al. 1995.

3 Zangheri 1988/1989.

4 Bandelloni et al. 1979, 19. 
flooding and thus equipped to start a profitable activity of land re-organisation. This ongoing tendency and interest in cultivating the lower plains to the east of the Euganean Hills is certainly due to the surrounding flourishing urban system linked to the cities of Padua, Venice, Chioggia and Monselice (fig. 8.2).

From the twelfth to the fourteenth centuries, urban development in inland Veneto, which was closely related to significant demographic growth, was also the sign of a remarkable economic upturn. The region was subdivided into restricted territories controlled by major independent city-states, whose political power was openly displayed in both civil and military building. In this historical context it is important to note the rise of several environmental conflicts, mainly affecting river and canal runoff management. One of the most cogent and well-known examples concerns the serious conflict between Vicenza and Padua over the exploitation of the Bacchiglione river. ${ }^{5}$ Due to its upstream location, during the first half of the twelfth century, Vicenza diverted most of the runoff from the Bacchiglione river in order to make navigation possible along a canal that connected to a natural stream flowing through Monselice towards the southern Venice lagoon and giving Vicenza access to Chioggia and its saltpans. Such actions revealed the need for an overarching governance of the hydrography of the entire region, especially when this directly affected the increasing siltation of Venice lagoon. It follows that a more lasting protection of this aquatic environment would involve an overall management plan for most of the Veneto plain, and it was this geopolitical goal that led to much of Venice's fourteenth- and fifteenth-century military intervention, so much so that from 1484 a vast territory, approximately corresponding to the present day Veneto and Friuli regions, became the inland possession of the mighty seafaring city state of Venice. ${ }^{6}$

After this annexation, Venice, ever attentive to inland water conditions, was quick to perfect her control of the waters, starting in 1501 with the establishment of the Magistracy of the Savi alle Acque, which expanded into the Collegio alle Acque before being converted some decades later into the Magistrato alle Acque (the Venice Water Authority), which is still fully operational today. This Magistracy, together with the Magistracy of the Beni Inculti ('Uncultivated Resources', 1556), dedicated specifically to improving land by adopting procedures for drainage and irrigation, are proof of the institutional commitment of the government in the Venetian era (up to 1797), and their long-standing work has produced immense volumes of documentation and maps now to be found in the central archive of the Republic of Venice and in other peripheral

5 Selmin et al. 2008.

6 Cosgrove 1993. 


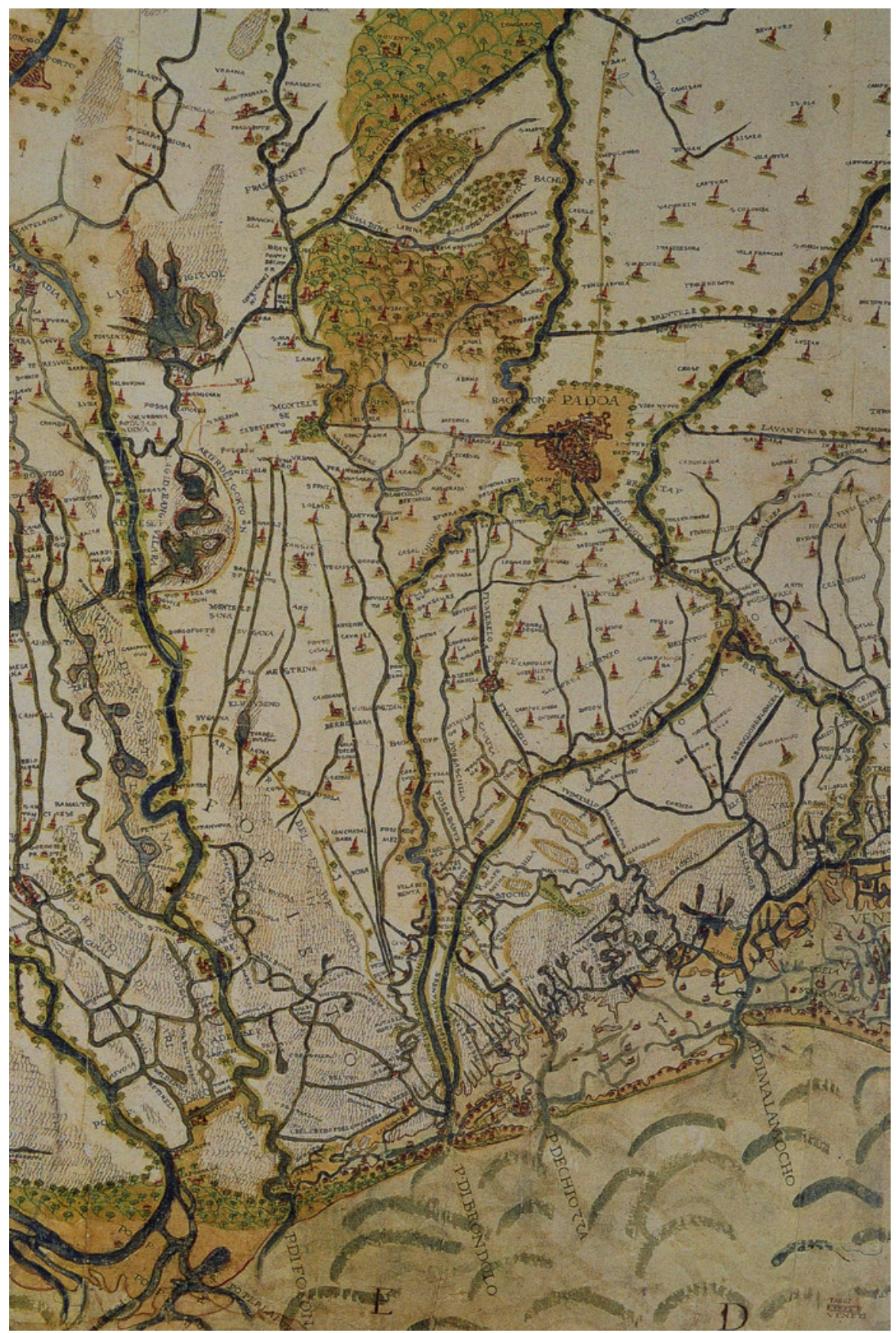

FIGURE 8.2 Low plain between Euganean Hills and north Adriatic shoreline in a mid-sixteenth century map of Cristoforo Sabbadino COURTESY OF ARCHIVIO DI STATO DI VENEZIA 
archives. ${ }^{7}$ Alongside this abundance of documentary and cartographic memory there is the equally substantial environmental heritage made up not only of watercourse routes but also of the ensemble of artefacts expressing the ageold familiarity of the Veneto people with the waterways and comprising river banks, bridges, water pumps, locks and riverside villas; all aspects of the historical and cultural identity of the lower plains.

Nautical relations on the Veneto terra firma should not only be related to the specific complexity of the hydro-geographic network, but also to the welldistributed presence of modestly sized residential settlements, mostly located near the banks of a natural river or of both major and minor artificial canals. In addition to the major river navigation routes connecting the main inland centres with the quaysides of Venice, and representing a fundamental and strategic interface between the trade routes to central Europe and the flow of superior goods from the East, there were also important routes heading towards Lombardy, Emilia and Friuli, and an equally important dense network of secondary connections making up the minor hydrographic network. The latter was a predominantly locally based system of relations (not always well documented), where the practice of navigation involved short-haul transport, within a single day, most frequently related to the daily needs of a riverside lifestyle (transfers from one side of the river to the other, fishing and hunting, gathering of marshland plants and reeds, domestic transport), rather than longer haul traffic.

The entire Stato da Tera (Mainland Domain), through to the innermost river wharfs where goods delivered by water were transferred from boats to carts for their subsequent destinations, was thus characterised by a series of "land roads, rivers and minor waterways, an immense network of regular and fortuitous connections, for perpetual distribution, as a virtually organic circulation." ${ }^{8} \mathrm{An}$ important aspect, in perfect harmony with the objectives of this study, concerns the recognition of all that remains today of the minor hydrographic network used in past centuries as a short-distance transport system. It comprised infrastructures with significant and articulate physical features, whose navigable routes, intersecting with the aims of reclamation and irrigation, revealed the peculiar character of a prestigious watery landscape.

In fact, until the widespread use in the late nineteenth century of steampowered water pumps for the mechanical pumping of water, vast territories in the low plains examined here had permanent marshland areas, at times alternating with dense woodland, where the drainage systems of important

7 A.S.V. 1983; A.S.V. 1984.

8 Braudel 1986, 282. 
collectors undoubtedly represented opportunities for the aforementioned nautical connections on a local scale, given the objective difficulty in ensuring satisfactory transport overland, made problematic due to the frequent flooding and prolonged stagnation of water.

Bearing this in mind, fluvial navigation emerged as the most effective means of solving and strengthening economic relations between Venice and its inland regions, involving not only the trading powers of the Rialto markets or exclusive advantages for land owners, but also the entire series of short-range relations mentioned previously. Implicit proof of this activity can be found in the particular importance given to chorographic mapping of hydrographic elements, detailed on the maps with painstaking precision, also highlighting the role of the pre-eminent connection between the centrality of the lagoon and a prosperous and well-populated terra firma (fig. 8.3).

Finally, inland navigation itineraries also had the purpose of connecting Venetian land investors with their villas, many of which could be reached directly by waterways. Water run-off regulated with sluices, canals confined between banks, bordered by shady rows of trees, facilitated relations between the city and the countryside (and not only in the flat Venetian terra firma) and were also themselves harmonious features of the landscape, an occasion for leisure to enliven the souls of those walking along the banks, but also for those sailing through. And here it is worth remembering the praise of Palladio for fluvial sites and the construction of country villas:

"If one can build on the river, it would be most pleasing and convenient; thus at little cost the boats may carry their ware directly to the villas, which will help the needs of the household and the animals, while the water would make the air cool in the summer, and create beautiful views. Thus both admirable and practical, the river would serve to irrigate the land, the grounds and the cottage gardens, which are the very heart and pleasure of the Villa. But navigable rivers cannot be had, and we shall attempt to build upon other running waters, moving away above all from the stagnant unmoving water, as this generates such unpleasant air." ${ }^{\prime}$

\section{Austro-Italian Reorganisation $\left(1815^{-1900)}\right.$}

The constant perfecting of techniques for the mechanical drainage of wetlands and the spread of specific irrigation methods are some of the main reasons behind a more effective application of hydraulic engineering expertise not only

9 Palladio 1570,45 . 


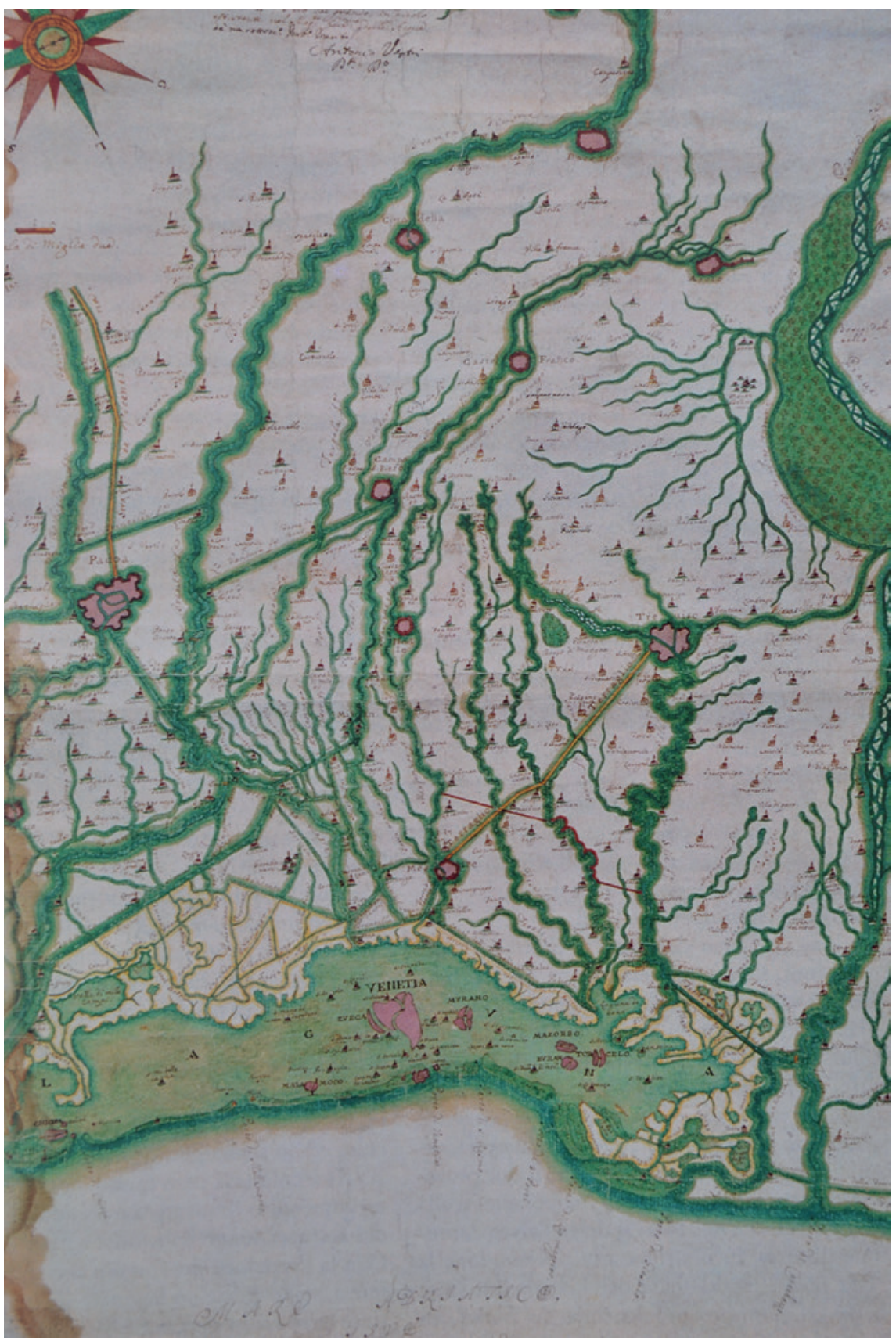

FIGURE 8.3 Fluvial navigation network in Venice inland in 1709 Antonio Vestri's watercolor map COURTESY OF ARCHIVIO DI STATO DI VENEZIA 
to the low plains next to the northern Adriatic Sea, but also to much of the Po Valley. During the Napoleonic Era, the authorities passed a Royal Decree on 6th May 1806 intended to simplify the fragmentation of the extension of the Consorzi (large consortia of landowners aiming at reclamation schemes) by incorporating them in larger territorial divisions known as Circondari. The establishment of these bodies was intended to simplify the coordination of land drainage measures as well as the maintenance of river banks along the main watercourses to prevent the risk of collapse during floods. ${ }^{10}$ In that period, the operating rigour of the French engineers of the Corp des Ponts et Chassueés provided a valuable lesson that had a considerable impact on the technical skills of Lombardy-Venetia officials. These engineers promoted the adoption of a broader approach to design, which placed individual operations within the overall functional context of the river basin concerned. Increased focus on fluvial processes together with re-established land reclamation operations laid the foundations for land modernisation, which was further boosted following the Unification of Italy. ${ }^{11}$ The chimneys of the steam dewatering pumps towered against the horizon of the flat lowlands, not unlike the initial concentration of factories around urban centres, which were connected by fire-breathing locomotives, whose increasing presence was to contribute to the decline of river transport throughout Europe. The debate over the role of inland navigation captured the attention of both technicians and investors, whose expectations needed to be followed up by appropriate policy choices.

In this regard, we cannot fail to notice the extraordinary complexity of the progressive accumulation of drains, channels, and ditches toward the shoreline, channelling waters to increasing numbers of dewatering facilities. These in turn connected to an infinite network of additional segments used not only for the prevailing drainage needs, but also for the opposing, and increasingly urgent demand for irrigation. We are thus faced with an amphibious landscape whose anatomy and physiology are closely linked to intensive agricultural production, while relationships with navigation were inseparable until the middle of the last century. This is especially the case of the riverside locations of sugar mills and of the imposing flour milling facilities, all key economic centres benefitting from the presence of an active fluvial fleet.

With the return to Austrian government, and a general context of political uncertainty, the Veneto's hydrographic management suffered consistent delays, thus preventing regular dredging of river and canal beds. As early as 1821, engineer Marco Antonio Sanfermo emphasised the difficulty of maintaining

10 Sanfermo 1833.

11 Cavallo 2011. 
regular traffic along the Brenta Nova river route in a handwritten memorandum: "Due to its oversized sections there is too little water for the passage of boats [...] except for some very light vessels from Chioggia." ${ }^{2}$ The above is just an account of the general decadence affecting the waterway system during the first half of the nineteenth century, mainly due to the difficult political atmosphere of the times and the inefficient and irregular maintenance of embankments and facilities, which were all too frequently damaged by disastrous floods. ${ }^{13}$ Yet, paying greater attention to fluvial waterway connections should have been a top priority, given that travelling by land was precarious at best in large areas of Veneto's lowlands, and was made more so by the prolonged rainfall during the autumn and winter seasons, well documented in an early nineteenth-century manuscript describing the streets around Padua's lowlands, "they are so bad and disastrous that one cannot tread upon them without putting one's life at great risk and peril."14.

A recurring theme among early nineteenth century essayists when describing Venice's inland hydrographic network, and particularly the one affecting the low plains between the Euganean Hills, Padua and the Adriatic Sea, is the apparent inefficiency of the receiving water bodies, which not only prevented smooth navigation, but also, in some conditions, failed to facilitate the flow of water from the drains of the surrounding countryside. These waterways were in fact "in such bad shape that they cannot receive drainage from lands that are inclined in their direction: this state of chaos is in addition to lost navigation in times of high and low water, stunted and precarious in the intermediate phase." 15

On a larger scale, similar problems may be observed along the major Po waterway, especially with ascending traffic, because of the "very physicalhydrographic configuration of the river [that] was not conducive to the development of navigation, made difficult, above the mouth of the Oglio river, by the steep gradient, the variability of the riverbed and shallow depths at times of low water."16 The prospects for the development of navigation were also conditioned by flow irregularities that made the use of mechanically propelled boats rather ineffective, as in the case of the Eridano, the first steamboat launched on the Po river in $1820 .{ }^{17}$ After the 1819 opening of the Naviglio Pavese canal connecting Milan to Pavia and then to the Po river waterways, navigation

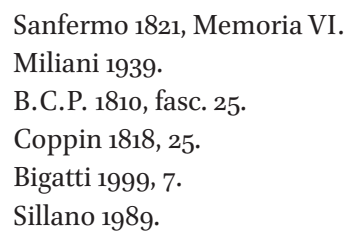


along the latter could still benefit from a direct link with the port of Milan, although the continued use of archaic propulsion techniques such as the power of currents, rowing, sailing, towing with animals from towpaths made fluvial transportation slow, and less attractive to businessmen and traders.

At the end of Austrian domination in the Veneto region (1866) there was a considerable decline in the use of inland waterways. This process of abandonment involved most inland navigation itineraries, especially when overlapping with railway links, while new conflicts arose as a consequence of the spread of new hydraulic schemes related to the dominance of the coeval reclamation interests. ${ }^{18}$ On the other hand, the modern improvement of water engineering, widely extolled as a matter of national pride since the beginning of Regno d'Italia (1861), eradicated most of the traditional practices connecting riverside populations to 'their' waterways. Hydraulic modernity therefore meant the increasing loss of the riverine 'sense of place'. However, inland navigation problems were seriously neglected and it was not until 1878 that the Ministry of Public Works (Lavori Pubblici) drew up a detailed Report on Italian waterways in order to foster a new political and economic trend, approaching inland navigation as an important national issue. ${ }^{19}$

Following the abovementioned 1878 National Report, many private initiatives were set up with the aim of modernising navigation on waterways by making use of steam engines and improving both traditional boating and hydrographic connections. These private initiatives included a carefully planned Government programme involving the establishment of a National Committee in 1900 whose main aim was an extensive three-year analysis of the problem, followed by the publication of nine volumes on the matter in 1903. ${ }^{20}$ As expected, the main aim of the investigation was to develop a vision where inland navigation could help the Italian economy to catch up with other European countries, as well as highlighting the need to apply a multifunctional approach to the improvement of waterways to obtain a more effectual territorial management.

\section{Minor Rivers and Traditional Vessels}

While on one hand (just as in the rest of Europe), Italy experienced the extraordinary competitive pull of railways, on the other, it is also true that

\footnotetext{
18 Lanaro 1984.

19 Ministero dei Lavori Pubblici 1878.

$20 \quad$ Ministero dei Lavori Pubblici 1903.
} 
transport by means of small vessels stayed alive up until just after the First World War, even though the continued survival of this 'neighbourly traffic' in a context of increasing national modernisation may have appeared rather curious and backward. Despite the inadequacy of the network of minor rivers and canals in this generalised drive towards technological progress, it is however plausible to presume that the Veneto area maintained the usual short-range nautical habits, documented in previous centuries by numerous comprehensive reports, often supported by cartographic surveys. However modest, local heritage related to local people's familiarity with and closeness to waterways was still detectable throughout much of Veneto's hydrography, resulting in a wide range of artefacts such as old mooring docks hidden by mud and weeds, rustic wooden piers, rural villages, or individual farmhouses overlooking rivers and canals and connected to them by means of short narrow flights of stone steps on their banks (fig. 8.4).

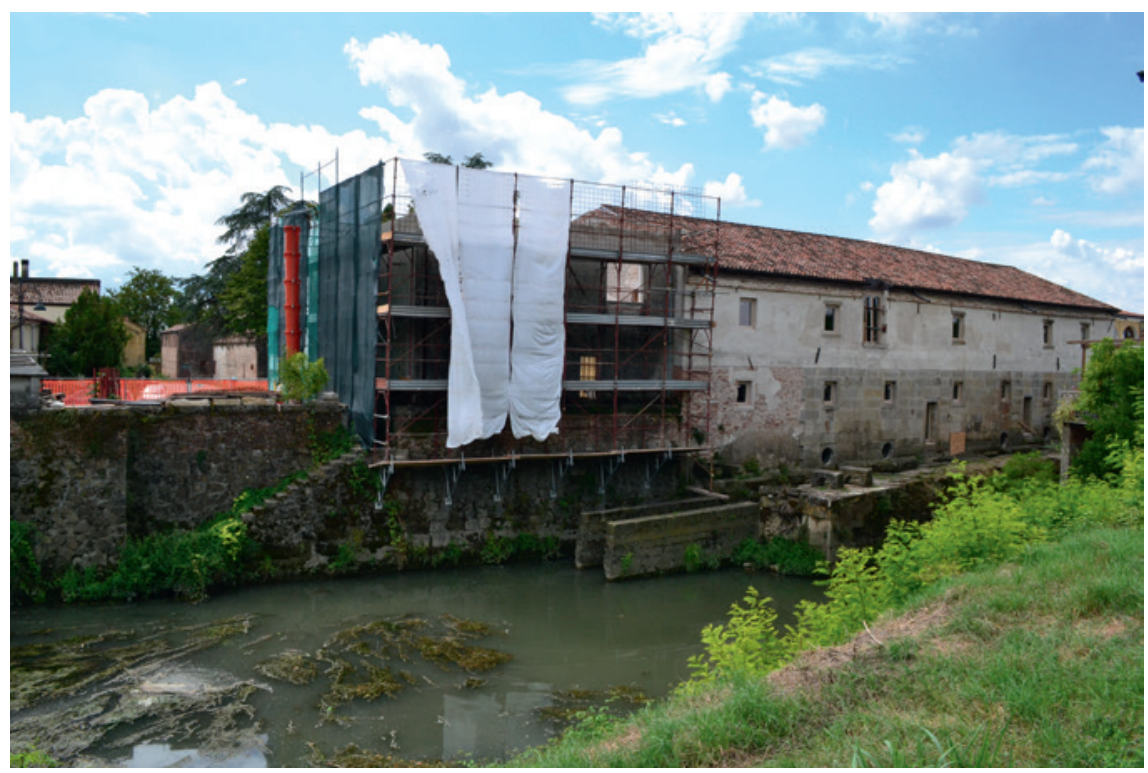

FIGURE 8.4 Recovering seventeenth century water mill, with stone steps leading to mooring dock

PHOTO FRANCESCO VALLERANI

Thanks to local scholars, some of them directly involved in agricultural and small industry improvements as entrepreneurs or landowners, the geoeconomic analysis of the potential of Venice's secondary inland hydrography has been carried out with considerable accuracy. This growing interest has involved modernisation programmes of the waterways flowing in the low plain, 
with the shared goal of bridging the gap between tradition and European modernism. However, it is worth pointing out that during the last decades of the nineteenth century the entire waterway network linking Venice to the other fluvial harbours in northeast Italy was affected by serious neglect. This situation aroused worries that the decline of the hydraulic management of the whole region had compromised technical control over hydrological dynamics. It follows that the decrease of inland cruising was related to lack of adequate control and maintenance of artificial canals and rivers, particularly in the approaches to lagoons and estuaries.

As to minor rivers and canals, the publication of Monografia Statistica della Provincia di Venezia (Venice Province Statistic Report) in 1881 can be considered as the turning point of the revival of inland navigation along secondary waterways ${ }^{21}$, thanks to the detailed descriptions of itineraries, enhancing their profitability not only for transportation of products coming from recently reclaimed lands, but also for their functions in the complex management of low plain hydrological dynamics. $^{22}$

Another important example of the increasing attention paid to minor rivers and canals is the careful research on central Veneto hydrography carried out by the engineer Francesco Turola in $1889 .{ }^{23}$ Turola stated that a successful revival of local navigation had above all to concentrate on the improvement of the waterways between Padua and Venice, and between Padua and Este (a small town located south-west of Padua). Despite the fact that those watercourses follow almost exactly the same route as two important railways, Turola placed more emphasis on the advantages of "mutual aid" then on the harm caused by competition. ${ }^{24}$ His technical report also contains detailed drawings of the contemporary fluvial landscape where the hydrographic network flowed through a densely populated territory; most of the scattered houses and villages were actually built close to rivers or canal banks.

Turola pointed out that in order to be more profitable, inland navigation ought to include secondary waterways, which could in fact promote closer commercial links, not only among the main regional towns, but also among local markets, as well as encouraging more profitable trading relationships in areas of the countryside that were distant from railway connections. Throughout his report there was a distinctly nostalgic attitude and regret for the passing of inland nautical traditions. Turola's proposals concerning inland

\footnotetext{
21 Sormani Moretti 1881.

22 Vallerani 2008.

23 Turola 1889.

24 Turola $1889,10$.
} 
navigation had no effect in improving the water transport along the secondary fluvial network, while greater interest was devoted to the main regional and inter-regional waterways.

Even within the framework of an attentive and thorough debate regarding the revival and modernisation of Italian inland navigation, the vessel types, their tonnage, and means of propulsion were clearly characterised by technological inertia. Most of the traditional cargo boats maintained the practice of animal towing and the use of sails until the period immediately after the Second World War, and engines were not used until the late nineteen-forties. This situation showed that river navigation had remained unchanged since the time of the Sanfermo's handwritten memoirs; in 1821 he drafted a detailed report listing the technical and operational data of all the vessels that sailed through Veneto's hydrography at that time. ${ }^{25}$

The large variety of boats found in his text reveals interesting functional differences mainly due to the differing widths and depths of the rivers and canals navigated, despite virtually identical construction principles in response to the needs of very similar fluvial environments. As for the smaller boats used to ferry passengers from one bank to another or for short trips, defined by Sanfermo as "assorted small boats," their diffusion was common in all the lower reaches of rivers and canals of the region. Furthermore, he states that such boats were not used for commercial reasons, but for the daily transport needs of hay, farm animals and feed, wood, including short navigations to mills and village markets. ${ }^{26}$ These types of boats also remained in use on the waterways of inland Veneto practically up until the demise of inland navigation during the nineteen-fifties.

\section{Towards New Landscapes}

The waterways of northeast Italy were included in effective modernisation programmes during the Fascist period, adopting the most up-to-date designs for the expansion of sluices along with mechanised manoeuvres, using metal structures for swing bridges, cutting and adjusting the most tortuous bends, consolidating embankments, and widening towpaths. Furthermore, these inland waterway-promoting activities had to be coordinated with land reclamation operations that led to the installation of new siphon culverts and the improvement of existing ones, along with the enhancement of electrically powered dewatering stations. New river landscapes began to form as a result of

25 Sanfermo 1821.

26 Pergolis 1989. 
the process of rural modernisation promoted by the regime. However, as mentioned previously, the numerous photographic campaigns celebrating this successful land recovery operation show that this widespread structural upgrade continued to host vessels that were virtually unchanged not only since Marco Antonio Sanfermo's reports in the early nineteenth century, and built in accordance with age-old Venetian traditions. The result is the curious coexistence between the new fast-filling lock-chambers and archaic sailboats such as the burchio and trabaccolo and even batela, smaller auxiliary boats transporting ropes intended for animal hauling.

This striking contrast and coexistence between modern frameworks and old boating habits would be partly overcome as boats were gradually motorized and larger boats were built, despite the fact that the ancient morphology of the hulls remained unchanged until recent developments made in shipyards. Furthermore, the system of nautical relations regarding the predominant routes connecting Lombardy to the Venice and Trieste harbours was part of the strategic interests of the new, post-First World War Italy, aimed at achieving greater land development efficiency, deemed an indispensable requirement. A major boost in this direction came from the economic writings of the time, especially those produced by the many local inland navigation committees, themselves stimulated by the objective nation-wide significance of the new port and industrial site of Marghera.

The renewed prospects of the Venetian port became the object of praise: the port was not only open to global trade but also invigorated by a great production centre well-connected to a flat hinterland. Located a short distance from steep Prealpine elevations, offering plentiful supplies of running water that could be transformed into abundant power, the surrounding territory was also connected "to many coastal canals and various rivers that, though not very large and deep, flow for many miles through rich and industrious regions." ${ }^{27}$

Reviving the port of Venice meant first of all recalibrating and improving the internal waterway network formed by Trieste, Treviso, Padua, and the Po route. The need for the continued maintenance of rivers and canals was also emphasised with regard to minor rivers and canals. This was not so much to meet the glowing expectations of intense modern industrial production destined for national and international markets, but to ensure product distribution in an almost pre-autarkic fashion, in other words connected to a well-organised and profitable agricultural activity supported by fertile soil rich with water: "the industries of Padua's province are as closely tied to its agriculture as is trade." In fact, this required "an intense commercial movement of capital, fertilisers, 
seeds, pesticides, and the sale of products," ${ }^{28}$ transporting abundant quantities of product for processing (cereals, beets, vegetables, grapes) from reclaimed land.

The renewed interest in the port of Padua may be understood along the same lines, "located in the fertile heart of the Veneto Region, where agriculture is strongly promoted, an important industrial, commercial, and financial centre, Padua should be the hub of a vast network of navigable waterways. It should have an efficient port equipped with modern docks and ample facilities for the temporary storage of goods."29 Padua's fluvial enhancement involved challenging structural work that improved the waterway towards Marghera and Venice. Old Venetian Era locks, unable to accommodate the new 300tonne vessels, were replaced, and a series of excavations were started to adjust the bed section of the Naviglio della Brenta canal.

In this context of design fervour, fuelled by the regime's rhetorical use of public works, the new Battaglia lock is worth mentioning as perhaps the most important work of Veneto's entire waterway system (fig. 8.5); it was the key node allowing boats to go from the Battaglia Canal to the underlying waterway heading towards the Bacchiglione and vice versa, overcoming a difference in water levels of over 7 metres. Work began in 1919 and ended in the spring of 1923. In addition to the real benefits for river traffic, this undertaking was invested with a far from negligible symbolic value. Its design included a rapidly filled basin and gates driven by an innovative water pressure mechanism, avoiding the consumption of power, evoking the capacity to exploit local potential efficiently while saving time, thus dealing with 'speed', the most successful of modernist metaphors. Such a rapid solution to the difference in the levels of the two canals ${ }^{30}$ and the faster nautical connections along the routes to the south of Padua were a clear contribution to the country's modernisation objective $\Omega$ issolini could not miss this opportunity and inaugurated the work on 1st June 1923, thus starting the epic national era of large-scale artificial hydraulic works.

The strategic advantages brought by efficient hydrography led to the revival of the waterway system, encouraged by the Fascist Regime's nationalistic ideology focused on the strengthening of rural infrastructures. The national publication of various geographical studies on economic and morphological issues related to inland navigation proved useful in drawing attention to the matter, as well as stressing the functional relevance of such issues for the lowlands,

\footnotetext{
28 Milone, 1929, 276.

29 Cigana $1923,6$.

$30 \quad$ Cucchini 1931, 172.
} 


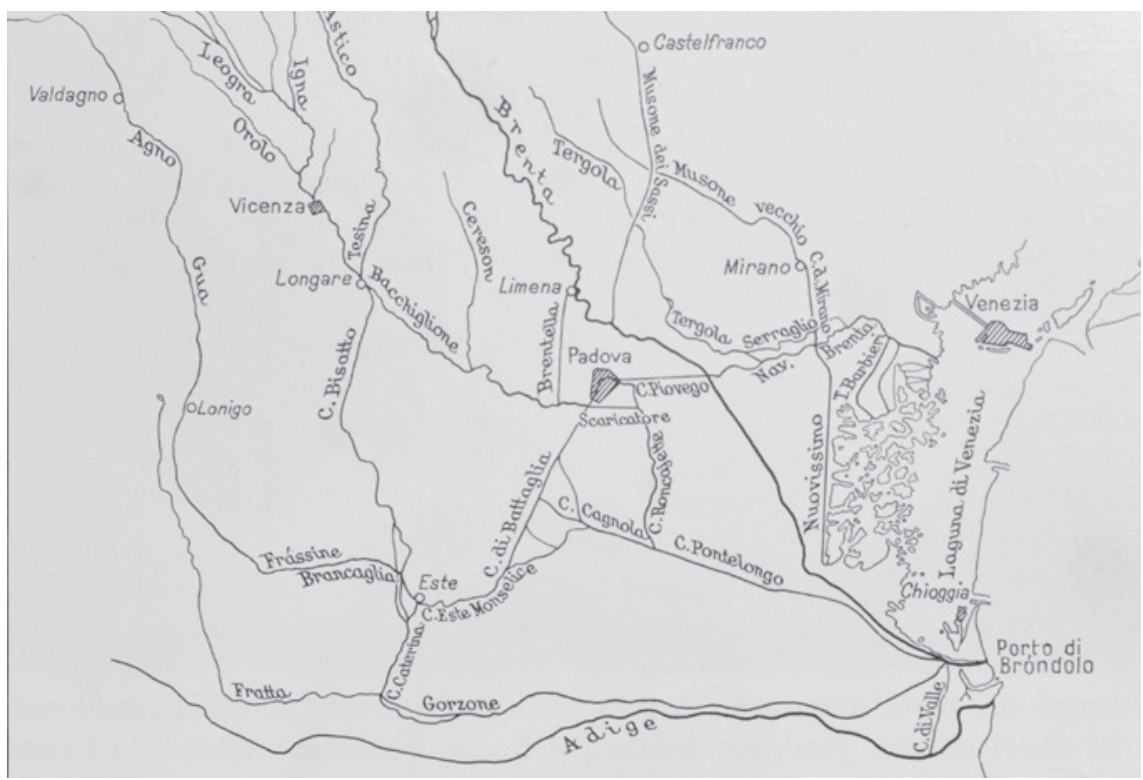

FIGURE 8.5 Central Veneto waterways system focused on both Battaglia canal and Padua inland harbor (after Migliorini 1962, 106)

which were rich in rivers and canals. ${ }^{31}$ According to these general goals, the role of the Paduan Scuola di Applicazione per Ingegneri (School of Engineering) was closely related to the governance of land use problems throughout the low plain along the north Adriatic shoreline, such the 1926 flood that affected vast swathes of the region. To improve research work on flood management, a laboratory for hydraulic testing was established at the Institute of Hydraulics at Padua (1933), where specific attention was paid to sluices, siphon spillways, mechanical drainage, irrigation, and measures to prevent riverbed flooding. ${ }^{32}$ Subsequently, inland navigation was closely linked to other hydraulic issues, which arose from irregularities in river flows mainly in the Venetian estuaries. The town centre of Padua, for instance, was served by many waterways, which proved efficient, yet at the same time exposed the town to frequent flooding. Flood prevention was eventually ensured by the hydraulic improvement of the town, which involved the excavation of new canals, riverbed modifications, and lock and dam construction. ${ }^{33}$

\footnotetext{
31 De Stefani 1925; Migliorini 1934.

32 Marzolo 1963.

33 Ferro 1927.
} 


\section{Recovering Water Memories and Sustainable Governance}

Documented in detail by the archives and various manmade structures scattered along the banks and in the vicinity, the effective evolution of hydrography can provide additional information to supplement the stories of those who have long experienced the changing inland waterfronts. While researching water memories through fieldwork and with the aid of historical geography and cultural anthropology methodologies, it becomes increasingly difficult to detect the vestiges left by centuries of land and water development throughout the intricate network of natural and manmade waterways running through the lower plains surrounding the Adriatic coastline. Scientific work in this context entails the analysis of environmental frameworks that have witnessed the consolidation of major river routes in addition to the unravelling of minor routes that connected scattered houses and small villages during the long process of creating agricultural landscapes in land only slightly above sea level. It involves focussing on the remains of a cultural and environmental heritage left in the shadows, neglected, nearly functionally extinct, fading from memory, almost a 'holocaust' caused by the overwhelming onset of different economies, activities, and perceptions.

This unavoidable process of obsolescence may seem a little less dramatic in other situations, as in Battaglia Terme, a tiny town on the twelfth-century Battaglia canal heading towards south Padua, where a handful of competent and enthusiastic volunteers offer their constant and worthy commitment in the local Inland Navigation museum. These volunteers have set themselves the existential objective of retrieving the cultural components tying a wide range of hydrographic elements such as rivers, lagoons, and lakes to their riparian communities. The generous efforts of the guardians of water memories ${ }^{34}$ have long been supported by the activities of researchers from academia as well as of local cultural institutions. The work of these researchers has provided a rich bibliography, which expresses a stimulating cultural vibrancy, restoring significant land and river knowledge centred not only around navigation and boat building, but also around other related topics such as fisheries, ports, and the dynamics of riverside settlements.

Since the 1980s, a new, shared sensitivity has emerged from the need to retrieve the quality of the environment, to reevaluate specific geo-historical landmarks on all levels, and to study the complex vestiges left in the landscape to find concrete signs produced by economic and residential choices and the organisation of natural morphologies. This new approach has equipped itself 
with tools that are critical for coping with the relentless erosion of cultural heritage, intended not only as simple objects of value, but above all, with the landscapes that serve as their setting. This general observation has engendered an awareness of the extraordinary interest evoked by the morphological and cultural contexts pertaining to water landscapes, be they lagoon, coastal, lake, or river areas. The impressive extent of the hydrographic network of the Venetian hinterland soon revealed the valuable potential for a successful renewal of land development dynamics, which led only in part to an actual improvement of the Veneto urban planning. Despite the lack of effective management of environmental heritage, there have been significant episodes based upon conscious and durable governance aimed at recovering large fluvial sectors, to the extent that being defined as a 'water town' (città d'acqua) is now deemed a prestigious award by several municipalities. In this respect, action has been taken not only along urban hydrographic stretches, but also along fluvial waterways connected to prestigious buildings, as well as rural villages and settings not overly compromised by intensive land use.

The whole of Europe is an endless repository of water-related stories simply waiting to be re-evaluated, surveyed, and carefully catalogued in order to combat the silent hidden impoverishment of a significant aspect of this continent's cultural heritage. Narratives of land and water-related events may be considered as an indisputable heritage and benchmark for the protection of local character as well as of old docks, boat repair yards, mills, bridges, and riverside pubs. These all form a unique tangible heritage requiring the attention of local communities to avoid dispersing the precious memory of a secular and fruitful relationship between humans and waterways. It follows that the current consolidation of new perceptions and assessments of lesser-known landscapes also involves local administrators, who have been increasingly more attentive to the identifying features of their territories.

The issues discussed so far have shown the importance of Venice's inland nautical heritage. It is worth mentioning that today there is an increasing awareness of the importance of waterways, in terms of both their touristic and recreational value. As a matter of fact social attitudes are revealing an increased appreciation for fluvial environments insofar as they provide ideal settings for sports and recreation as well as opportunities for cultural tourism. Hydrographic atmospheres belong mostly to rural landscapes eschewin urban development making it possible to define waterways as 'cultural corridors', that is a repository of manufactured items related to specific hydraulic functionalities, but also of Venetian villas, old churches and chapels, traditional farm houses and water mills (fig. 8.6). Many of these buildings have become landmarks for tourism along European rivers, even being transformed 


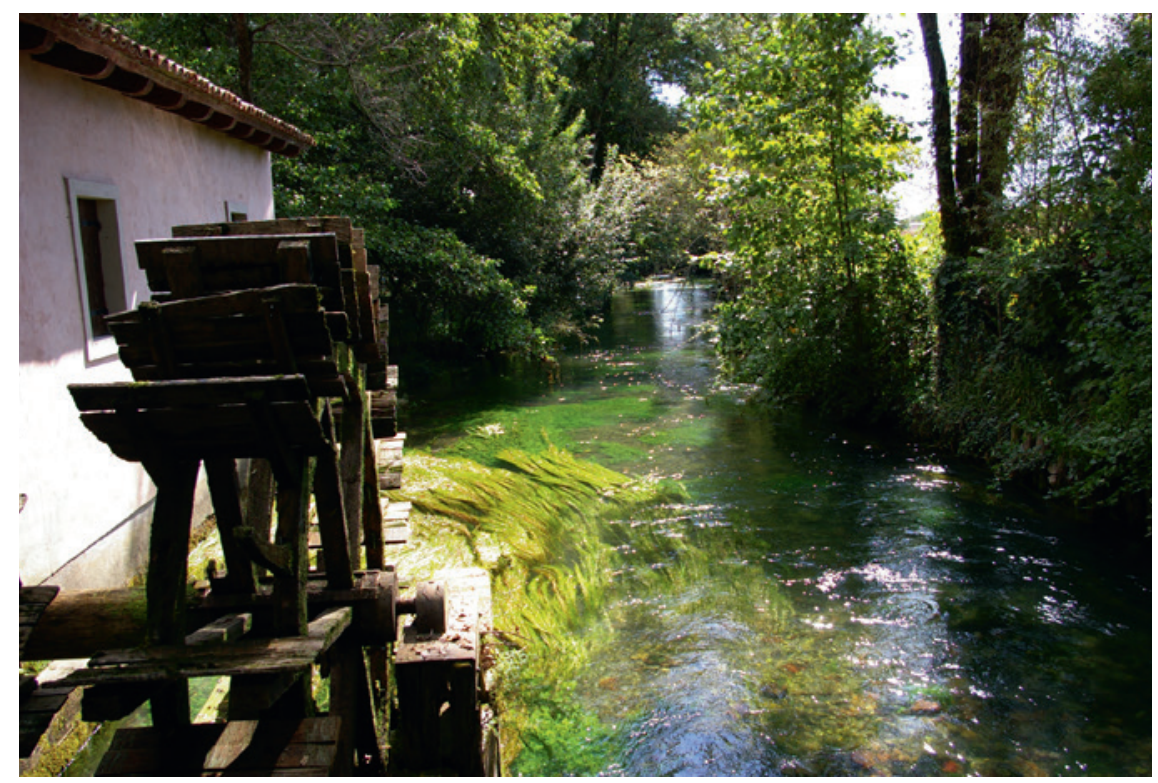

FIGURE 8.6 Water mill as fluvial heritage and now landmark for a new development of cultural tourism PHOTO FRANCESCO VALLERANI

into thematic museums also involving the surrounding environment. In countries such as Britain, France, Belgium, Holland, and Germany, the established practice of tourist travel along inland waterways, or the aforementioned 'cultural corridors,' has stimulated the recovery of almost all the locks necessary to fluvial navigation, and encouraged new businesses to reopen of old river inns, thereby facilitating friendly and lively encounters among land and river travellers.

Matters concerning fluvial tourism should be addressed by means of specific governance strategies aiming at the strict safeguarding and restoration of the natural environment, in order to satisfy the growing demand for attractive leisure spaces providing opportunities for city dwellers to relax and regenerate physically and psychologically. The prospects outlined here concerning the promotion of tourism in the area should obviously aim not only to increase the number of visitors, but, as just mentioned, should also respond to the growing demands of residents wishing to improve the quality of day-to-day living. The humanisation of living space does not only mean taking care of the physical locations, but also involves finding the means to satisfy the habitation needs of the local population, recapturing the pleasures of social relations, and therefore encouraging a more aware sense of place. 
The final hope and aim of the proper governance of the Veneto's inland waterways is the co-existence of recreational use by local residents and the tourism supply for visitors, while emphasising that these vocations should be able to achieve what is normally defined as 'innovation', a strategic key word, rather obsessively used in these recent years of general economic decline. Real innovation lies in giving due importance to the landscape heritage, the quality of water, the condition of green areas, local agriculture, rediscovering traditional food and recipes, and fostering a slower pace of life, all aims capable of increasing the 'competitive edge' (yet another key phrase of recent years) of a territory, measured also in terms of the satisfaction experienced by residents living in a healthy environment where local tangible assets are also protected. The case study considered here could finally be seen as a testing area where it is worthwhile to encourage the familiar approach of participation in order to demonstrate how many advantages can ensue from the conscious restoring of relations between communities and waterscapes.

\section{Bibliography}

A.S.V. 1983: Archivio di Stato di Venezia (A.S.V.), Laguna, lidi, fiumi: cinque secoli di gestione delle acque (Venice 1983).

A.S.V. 1984: Archivio di Stato di Venezia (A.S.V.), Cartografia, disegni, miniature delle magistrature veneziane (Venice 1984).

Bandelloni et al. 1979: Bandelloni, E. - Zecchin, F., I Benedettini di Santa Giustina nel basso Padovano (Padua 1979).

B.C.P. 1810: Biblioteca Civica di Padova (B.C.P.), Piano e regolamento stradale per la provincia di Padova (control number: B. P. 824).

Bigatti 1999: Bigatti, G., La navigazione del Po fra mito e storia (secoli XVIII-XIX), in: Foresti, F. - Tozzi Fontana, M. (eds.), Imbarcazioni e navigazione del Po. Storia, pratiche, tecniche, lessico (Bologna 1999) 1-45.

Bondesan et al. 2004: Bondesan, A. - Meneghel, M. (eds.), Geomorfologia della provincia di Venezia. Note illustrative della carta geomorfologica della provincia di Venezia, Mito e la storia. Serie maggiore 5 (Padua 2004).

Braudel 1986: Braudel, F., Civiltà e Imperi del Mediterraneo nell'età di Filippo II. (3rd ed. Turin 1986).

Cavallo 2011: Cavallo, F. L., Terre, acque, macchine. Geografia della bonifica in Italia tra Ottocento e Novecento, Passages 12 (Reggio Emilia 2011).

Cigana 1923: Cigana, E., Sulla navigazione interna nel padovano. Studi e proposte (Padua 1923). 
Coppin 1818: Coppin, P., Breve saggio intorno ai canali irrigatorj e navigabili (Padua 1818).

Cosgrove 1993: Cosgrove, D., The Palladian Landscape. Geographical Change and its Cultural Representations in Sixteenth-century Italy (Leicester 1993).

Cucchini 1931: Cucchini, E., La navigazione interna dell'alta Italia. XV Congresso internazionale di navigazione, Venezia, settembre 1931 (Rome 1931).

De Stefani 1925: De Stefani, A., L'azione dello Stato Italiano per le opere pubbliche (1865-1924) (Rome 1925).

Ferro 1927: Ferro, G., Navigazione interna (Padua 1927).

Jori 2009: Jori, F., Lultimo dei barcari. Riccardo Cappellozza, una vita sul fiume (Pordenone 2009).

Lanaro 1984: Lanaro, S., (ed.), Storia d'Italia. Le regioni dall'Unità ad oggi, vol II: il Veneto (Turin 1984).

Mainardi 2012: Mainardi, M., Zingari d'acqua. L'epopea dei barcari della bassa pianura Padana nella vicenda di un vecchio navigante (Venice 2012).

Marzolo 1963: Marzolo, F., Costruzioni idrauliche (Padua 1963).

Migliorini 1934: Migliorini, E., Appunti sulla navigazione interna e sul traffico nei fiumi e canali italiani, Bollettino della Reale Società Geografica Italiana 6, 1934, 211-226.

Migliorini, E., 1962. Il Veneto. Torino: UTET.

Miliani 1939: Miliani, L., Le piene dei fiumi veneti e i provvedimenti di difesa. L'Agno-Guà-Frassine-Gorzone. Il Bacchiglione e il Brenta, Pubblicazioni della Commissione italiana per lo studio delle grandi calamità 8 (Florence 1939).

Milone 1929: Milone, F., La Provincia di Padova. Studio di geografia economica (Padua 1929).

Ministero dei Lavori Pubblici 1878: Ministero dei Lavori Pubblici, Cenni Monografici sui singoli servizi: sezioni V (Fiumi) e VI (Navigazione Interna) (Rome 1887).

Ministero dei Lavori Pubblici 1903: Ministero dei Lavori Pubblici, Atti della Commissione per lo studio della navigazione interna nella valle del Po, vol. 1-9 (Rome 1903).

Palladio 1570: Palladio, A., I quattro libri dell'architettura. Il secondo libro dell'architettura (Venice 1570).

Pergolis 1989: Pergolis, R., Il naviglio del Canale della Battaglia, in: Zanetti, P. G. (ed.), La Riviera Euganea. Acque e territorio del canale Battaglia (Padua 1989) 149-162.

Rotondi et al. 1995: Rotondi, G. - Zunica, M., Il lido di Sottomarina. Processi interattivi di costruzione e consumo (Padua 1995).

Ruggeri 1922: Ruggeri, L., Venezia e la navigazione interna, Rivista Mensile della Città di Venezia 1 (12), 1922, 1-12.

Sanfermo 1821: Sanfermo, M. A., Della situazione di Brenta e Bacchiglione e dei modi di migliorarla. Padova Biblioteca Civica Manuscript 3 vol. (control number B. P. 1780$)$. 
Sanfermo 1833: Sanfermo, M. A., Lettere descrittive di alcuni luoghi campestri nelle Provincie Venete (Venice 1833).

Selmin et al. 2008: Selmin, F. - Grandis, C. (eds.), Il Bacchiglione (Sommacampagna 2008).

Sillano 1989: Sillano, M. T., I sommi vantaggi della navigazione a vapore nel LombardoVeneto, in Rainero, R. - Bevilacqua, E. - Violante, S. (eds.), L'uomo e il fiume. Le aste fluviali e l'uomo nei paesi del Mediterraneo e del mar Nero (Milan 1989) 137-143.

Sormani Moretti 1880/1881: Sormani Moretti, L., La Provincia di Venezia. Monografia statistica economica amministrativa (Venice 1880/1881).

Turola 1889: Turola F., La navigazione fluviale e la provincia di Padova (Padua 1889).

Vallerani 2008: Vallerani, F., (ed.), Dalle praterie vallive alla bonifica. Cartografia storica ed evoluzione del paesaggio nel Veneto Orientale dal ‘50o ad oggi (Portogruaro 2008).

Zangheri 1988/1989: Zangheri, P., Dati paleo-idrografici sulla pianura a sud-ovest dei Colli Euganei, Atti e Memorie dell'Accademia Patavina di Scienze, Lettere e Arti 101, 1988/1989, 175-198. 